\title{
Does Firm Performance Impact Top-Level Executive Compensation in ESG Companies? Evidence from India
}

\author{
CHETNA RATH \& MALABIKA DEO
}

\begin{abstract}
The huge disparity in the pay given to higher level executives in Indian companies has stirred a nation-wide debate regarding the viability of the pay-performance concept. On the other hand, the top-notch businesses claim to be good social performers by adhering to the rules, regulations and norms prevailing in the country concerning the welfare of the community encompassing it; broadly referred to as Environmental, Social and Governance (ESG) companies. The purpose of this paper is to examine and determine the link between firm performance (taken as independent variable) and compensation pay (considered as dependent variable) of such large as well as socially responsible companies. For sample of the firms, data has been collected from NSE Nifty 100 ESG Index and data for all other measures has been extracted from CMIE Prowess database. Panel regression results indicate that Return on Equity (ROE) has a significant negative impact while stock return of investors do have a significant positive impact on the compensation pay. In order to overcome the persistent underlying endogeneity issue, One-step System Generalised methods of moments (GMM) estimator has been employed. The overall findings indicate that accounting measure of firm performance exerts a significant impact on the compensation paid to the executives in ESG firms of India.
\end{abstract}

Keywords: Pay-performance concept; socially responsible companies; executive compensation; firm financial performance; India

\section{INTRODUCTION}

With the rising stiff competition in the Indian market, there has been a constant and on-going effort by the firms to outperform the competitors through their performance and reputation building. One of the latest attempt taken in this direction is to channelize the resources of the entity by 'doing good' to the community at large. Such Corporate social performers are believed to follow all the laws, regulations, ethical practices and work towards the benefit of all the stakeholders; widely referred to as the Environmental, Social and Governance (ESG) companies. In this line, Clarkson (1995) had rightly quoted that CSR has become quintessential for the firms to secure their long-term competitiveness and accomplishments.

In a country like India wherein the unemployment rate is quite high and per capita income is low as compared to other countries, the compensation paid to the top-level executives has always been a buzzword leading to a spotlight debate. The Economic Times Intelligence Group (2018) also reports that top executives earn 243 times more than the average staff in Indian Inc. Reports given by Moneycontrol (2019) states that Indian Chief Executive Officer's Pay has outpaced company performance in the last five years. Recently in September 2019, the case of Altico Capital (India based NBFC) sent shockwaves to the country as it decided to pay its CEO more than half the money it had defaulted to Mashreq Bank in Dubai (U.A.E) (Reported by ET Prime 2019).

In a company form of business, there always exists an underlying 'Agency Theory' wherein the shareholders or investors are the real owners (also referred to as the 'principals') and they appoint managers (also referred to as the 'agents') to look after the day-to-day operations of the business. There arises a conflict of interests in this structure as it is believed that agents are often concerned about their personal interest and they do that at the expense of the principal. This theory of principal-agent relationship or the 'principal-agency theory' is also specified by the Companies Act which has provoked entities to design the compensation contracts that would align the interest of agents or managers with that of principals or shareholders. In an emerging country like India, where there has been a major overhaul in the governance legislation in the past few years; the research works to substantiate such changes has been very few. Ghosh (2006) has used 127 listed firms as a sample of the manufacturing sector to show that compensation of CEO has a significant impact on performance of the firm, especially in case of larger boards. Jaiswall and Bhattacharya (2016), on the contrary determined that compensation of CEO is associated with its tenure and ownership attributes which in the private sector is significant to future firm performance. Raithatha and Komera (2016) by using a considerably large sample of 3100 Indian firms, have stated that both market and accounting -based measures of firm performance has a significant impact on the compensation paid to the executives. Jaiswall and Firth (2009) also found a positive indication between CEO pay and firm performance. Parthasarathy et al. (2006) have stated that promoter CEOs tend to earn significantly higher than their ordinary counterparts while none of the measures of profitability is a significant determinant of CEO pay. All the above mentioned studies have thrown 
considerable light on the pay-performance link in the Indian context prior to the Companies Act 2013 regulation. These works hold great relevance and have paved the way for defining the research gap of the current work. Firstly, all the papers establish the strength of pay-performance link in Indian companies and also its related measures/ indicators that affect the same. This paper moves a step ahead and determines whether companies which are socially responsible do follow a similar pattern of pay-performance linkage. Secondly, with the new corporate law coming into force in the country, a substantial overhaul has been witnessed as concepts like 'Corporate Social Responsibility' and 'Key Managerial Personnel' was introduced; and eventually came into limelight. There was a transition in the operational activities, performance outlook and profit-distribution by the companies as the focus was shifted to stakeholder-welfare orientation rather than mere profitmaking. This paper therefore, is an attempt to determine the pay-performance relationship of socially responsible corporate entities in the backdrop of implementation of the new legislation.

Although some of the studies in India stated above throw light on the compensation and financial performance of Indian companies in general, to the best of authors' knowledge this is the first paper which considers the social responsibility factor in this context. By employing a unique dataset from Nifty 100 ESG Index, this study focuses on the recent developments of the Companies Act 2013 and its succeeding amendments related to the same. Moreover, to account for persistence of endogeneity in the model, System-GMM estimator has been employed in this work.

\section{LITERATURE REVIEW}

\section{CORPORATE SOCIAL RESPONSIBILITY AND EXECUTIVE COMPENSATION: THE INDIAN CONTEXT}

Philanthropic orientation to CSR has been in prevalence since long. However, it took a mainstream in our country when doors were opened to Corporates from all around the globe in the New Economic Policy 1991. As a mandate, CSR was first brought out in the Companies Act 2013 with a provision to spend about 2\% of the average net profits of preceding three financial years towards this cause (under Section 135, Companies Act 2013). Five years down the line The Economic Times, 2018 reports that CSR compliance is likely to fall within the range of 97\%-98\% by Financial Year 2019-20. Undoubtedly, CSR has become an essential ingredient of governance of corporate entities and has managed to carve out a niche for itself in the arena of Corporate Finance.

With an acknowledgement to increase the remuneration of the executives, the Ministry of Corporate Affairs in the Amended Managerial Remuneration Rules, 2016 requires all the listed companies to mention the name of top 10 employees (in terms of remuneration drawn) in its Board Report. Besides, the ratio of directors' pay to the employees and the increase in percentage of the remuneration of Key Managerial Personnel, directors and employees also needs to be stated in the report of Board of Directors along with necessary justifications thereof. Section 197 of Companies Act 2013 has an elaboration in detail about the maximum managerial remuneration to be paid in case of profits and in case of inadequate profits (Schedule V). Both the above corporate disclosure mandate would ensure transparency by the top level executives i.e. it would be a medium of communication to the stakeholders regarding the amount of remuneration drawn by the management team while keeping aside a portion of profits towards CSR.

\section{CORPORATE SOCIAL RESPONSIBILITY AND FIRM VALUE}

Enhancement of value of the firm and increase in wealth of the shareholders are two of the major parameters to judge the performance of any business. CSR being a long-term and intangible asset is said to improve the firm value by reducing the cash-flow risk (Chan et al. 2014 ; Gao \& Zhang 2013) and improving productivity (Kim \& Ouimet 2014). ESG firms carrying out CSR activities is proved to reduce subsequent risk and is also being used as an intangible asset for a long-term purpose to benefit the interest of all the stakeholders (Miles \& Miles 2013; Mukhtaruddin et al. 2019; Ronald et al. 2019). The companies also can avoid ESG and reputational risks by taking appropriate/effective CSR actions (Karwowski \& RaulinajtysGrzybek 2021).

Taking a look at the two Schools of Thought, wherein the first one relates to the agency cost, popularly known as the 'over-investment hypothesis', which argues that the managers try to over-invest in CSR activities to enhance their reputation which would eventually destroy the firm value (Barnea \& Rubin 2010). On a reverse note, firms use CSR engagement as a tool to reduce conflicts between the managers and non-investing stakeholders known as the 'conflict-resolution hypothesis'. This is when the external stakeholders would believe that executives would channelize funds/generated profits towards CSR activities that would ultimately result in betterment of the society. Thereby it would lead to reduction in conflict amongst different parties and shall increase the firm value (Freeman 1984; Gangi et al. 2019; Jo \& Harjoto 2011). Lastly, some researchers like Nelling and Webb (2009) have also argued the existence of neutral effect of CSR and Firm Performance. 


\section{EXECUTIVE COMPENSATION AND FINANCIAL PERFORMANCE}

Tosi et al. (2000) have stated that there has been a rising debate focusing on the relationship between executive compensation paid and firm performance derived. Research has also proved that different pay packages in the form of bonus or stock options are based either on sales or profit leads to difference in action of the executive team/CEOs (Abowd \& Kaplan 2017)

Coming to CEO perspective, classical agency theory suggests that the CEO's tend to pursue their own objective rather than considering the shareholders interest (Jensen \& Meckling 1976) and to enhance their bargaining power or reputation in the mainstream of the society (Barnea \& Rubin 2010; Milbourn 2003; Rasoava 2019). Jensen and Murphy (1990) in their work stated that there exists pay-performance sensitivity and firm performance shows a positive influence in CEO pay. The positive relationship between the two aspects is being given by Farooque et al. (2019), McGuire (2018), Waddock and Graves (1997), Griffin and Mahon (1997) while the negative relationship is indicated by Amewu and Alagidede (2021), Hasnan et al. (2020), Kline et al. (2017), Wright and Ferris (1997) among others. Works of Nicola et al. (2016) and Firth et al. (2006) established no relationship between both the constructs.

\section{CONTROL VARIABLES AFFECTING EXECUTIVE COMPENSATION}

Control variables affecting the compensation pay includes firm size, leverage, risk of the company, revenue from sales etc. that has been majorly stated by the past literature. In this study, two major factors or variables firm size and firm leverage has been used as control variables. Earlier studies like Amewu and Alagidede (2021), Yang et al. (2020), Rahim and Nelson (2018), Jaiswall and Firth (2009), Ghosh (2003), Core et al (1999), Murphy (1999) have induced firm size into their regression models as an explanatory variable. The general intuition behind including it is that bigger firms will be in a position to pay more to their executives owing to higher net worth or sales revenue. Using Firm Size as a control variable would capture any difference in pay structure arising due to the size of the enterprises used in the dataset.

When it comes to leverage of the firm, studies like Brisley et al. (2021), Ghasemi and Ab Razak (2020), Hasnan et al. (2020), Malik and Shim (2019), Mehran (1995), Lewellen, Loderer, and Martin (1987), Jensen (1986), Ross (1977), John and John (1993) have brought out the relation of debt financing and its corresponding effect on pay- performance concept. Leverage is considered as an alternative to the remuneration pay for firms having high cash-flows that can exert managerial discipline and enhance critical observation of use of debt-finance by the managers. High levered firms reduce the agency cost thereby lowering the incentives paid to the executives.

\section{RESEARCH METHODOLOGY DATA OF ESG COMPANIES}

As a measure of good social performers, data of ESG companies has been chosen as those firms are believed to be socially conscious because they do incline welfare criteria standards to the company's operations. Keeping our prime objective in mind, we have considered NSE NIFTY 100 ESG Index as our sample ESG companies as it reflects the companies' performance based on the Environmental, Social and Governance (ESG) factors. To be placed in the stated list, every company must be primarily categorized under NIFTY 100 first and should have a valid ESG score. Starting with a base value of 1000 as on $1^{\text {st }}$ April, 2011; the NIFTY 100 ESG stocks derive their weights from its free-float market capitalization on a bi-annual basis. Firms which have an ESG score of 4 and 5 or are engaged in anti-environmental businesses like manufacturing of weapons, gambling, alcohol and tobacco will not qualify to be listed in the above index.

On an initial stance, a total of 90 companies were derived under the NSE NIFTY 100 ESG Index from Centre for Monitoring Indian Economy (CMIE) Prowess Database which was then further filtered as per the availability of all the other necessary variables. The Prowess database is one of the leading databases in India which derives a large chunk of information from the annual reports of over 40,000 companies from different industrial sectors. Following Chakravarthy (1986), Khanna and Palepu (2000), Ghosh (2006) we consider this database for the study. Moreover, it also provides compensation and firmspecific data in relation to Indian ESG companies that we have used in our study. Out of the above sample, we have excluded financial service firms, firms from banking and insurance sectors as they are governed by their special acts and not Companies Act 2013.

Our final sample consists of 414 firm-year observations; which is a balanced panel of 69 firms for 6 years. The data is collected from 2014-2019 in order to determine the impact on remuneration post the implementation of Companies Act $2013^{1}$. The total list of companies is given in Table No. 1

TABLE 1. List of ESG companies

\begin{tabular}{ll}
\hline 1. A B B India Ltd. & 36. Interglobe Aviation Ltd. \\
2. A C C Ltd. & 37. J S W Steel Ltd. \\
3. Ambuja Cements Ltd. & 38. Larsen \& Toubro Ltd. \\
\hline
\end{tabular}




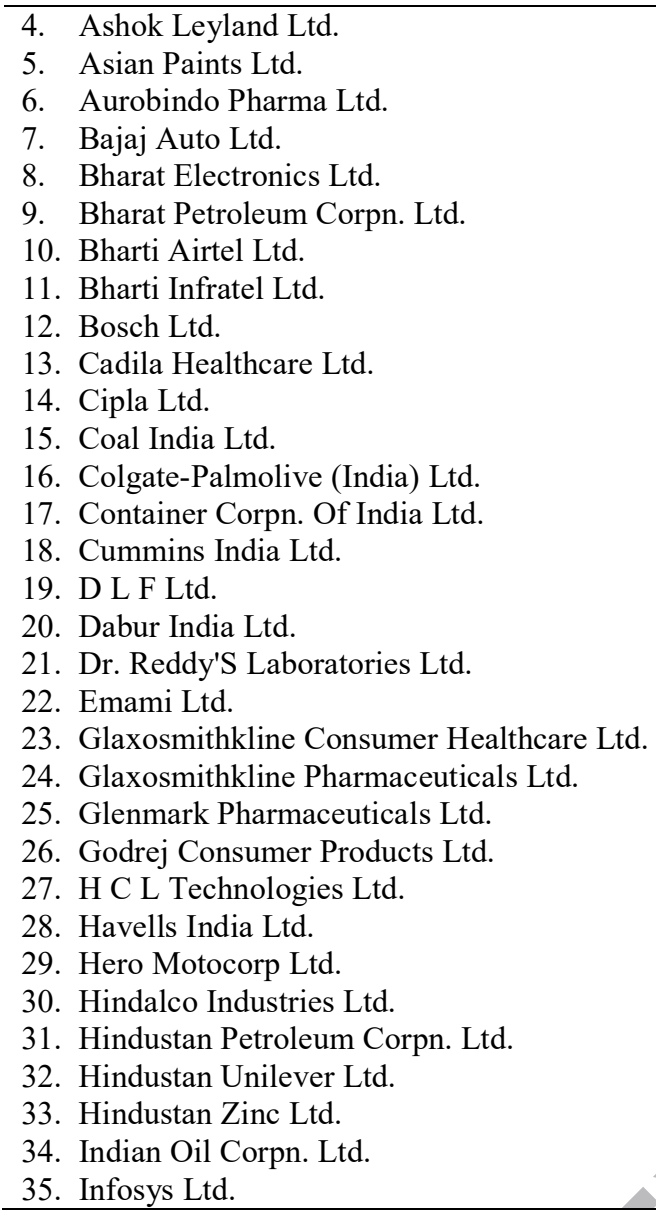

39. Lupin Ltd.

40. M R F Ltd.

41. Mahindra \& Mahindra Ltd.

42. Marico Ltd.

43. Motherson Sumi Systems Ltd.

44. N H P C Ltd.

45. N M D C Ltd.

46. Oil India Ltd.

47. Oracle Financial Services Software Ltd.

48. Petronet L N G Ltd.

49. Pidilite Industries Ltd.

50. Piramal Enterprises Ltd.

51. Power Grid Corpn. Of India Ltd.

52. Reliance Industries Ltd.

53. Shree Cement Ltd.

54. Siemens Ltd.

55. Steel Authority Of India Ltd.

56. Sun Pharmaceutical Inds. Ltd.

57. Sun T V Network Ltd.

58. Tata Motors Ltd.

59. Tata Consultancy Services Ltd.

60. Tata Steel Ltd.

61. Tata Power Co. Ltd.

62. Tech Mahindra Ltd.

63. Titan Company Ltd.

64. Torrent Pharmaceuticals Ltd.

65. U P L Ltd.

66. Ultratech Cement Ltd.

67. Vodafone Idea Ltd.

68. Wipro Ltd.

69. Zee Entertainment Enterprises Ltd.

\section{SELECTION OF VARIABLES}

For determining the sensitivity of pay-performance relationship, the consolidated total remuneration of the directors of the Board or top level executives has been taken into consideration as our dependent variable. For 'Top level Executives', compensation data of Managing Directors, Chief Executive Officers, Chief Financial Officers, Chairpersons, Executive Directors and other directors has been considered. For firm performance, both accounting and market measures of performance has been considered. Following Chen and Huang (2010), Raithatha and Komera (2016), Waddock and Graves(1997); Return on Equity(ROE) $)^{2}$ is taken as a proxy for accounting-based measure and Annual Stock Returns ${ }^{3}$ is taken as a representative variable for market-based measures. Firm size and financial leverage are taken as control variables as they can enormously affect the pay-performance sensitivity. Data for all the above-mentioned variables has been extracted from CMIE Prowess database; the description of which has been given in Table No. 2

TABLE 2. Variable definition

\begin{tabular}{cc}
\hline Variables & Description \\
\hline $\begin{array}{c}\text { Dir_Rem } \\
\text { ROE }\end{array}$ & $\begin{array}{c}\text { Consolidated pay to the top level executives that includes total of Basic Salary, } \\
\text { Options granted }\end{array}$ \\
Return & Return on equity or net worth \\
Size & Annual NSE stock returns that includes dividend and capital growth/appreciation \\
Leverage & Natural logarithm of total assets of the firm
\end{tabular}




\section{RESULTS}

To start with our analysis, we have tested unit-root stationarity through various methods (Levin, Lin \& Chu; Im, Pesaran \& Shin W-stat; ADF-Fisher Chi-square; PP-Fisher Chi-square) the results of which are untabulated. While Remuneration of Directors and Return on Equity components were stationary at first difference, other variables like Stock Returns, Firm Size and leverage were stationary at level. After taking into consideration the first difference, the data was analyzed using Pooled Ordinary Least Square (POLS) and Fixed Effects (FE) estimation. The general equation that is employed to study the stated objective can be given as:

$$
\text { Dir_Rem }{ }_{\mathrm{it}}=\alpha_{0}+\beta_{1} \mathrm{Y}_{\mathrm{it}}+\gamma \mathrm{Z}_{\mathrm{it}}+\varepsilon_{\mathrm{it}}
$$

Where Dir_Rem $=$ dependent proxy variable for consolidated executive compensation for $i^{\text {th }}$ company and time $t$, $Y_{i t=}$

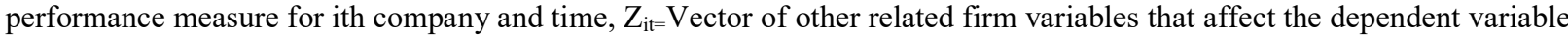
for ith company and time $t$ and $\varepsilon_{i t}=$ Error term/ residuals for $i^{\text {th }}$ company and time $t$;

For analyzing the complete study, a total of eight different specifications have been regressed separately. In Model 1 and Model 5, compensation to executives is taken as the dependent variable while Return on Equity (ROE) as the regressor variable. Model 2 and Model 6 takes into account of the effect of control variables i.e. size and leverage in addition to the previous model specification. Similarly, in Model 3 and 7, Stock Returns has been considered as the independent variable keeping the Remuneration of directors as the measured dependent variable. Lastly, Model 4 and 8 adds the control variable of size and leverage to the previous specifications, while keeping the dependent variable constant.

TABLE 3. Panel regression results of Panel Ordinary Least Squares (POLS) and Panel Fixed Effects depicting the pay-

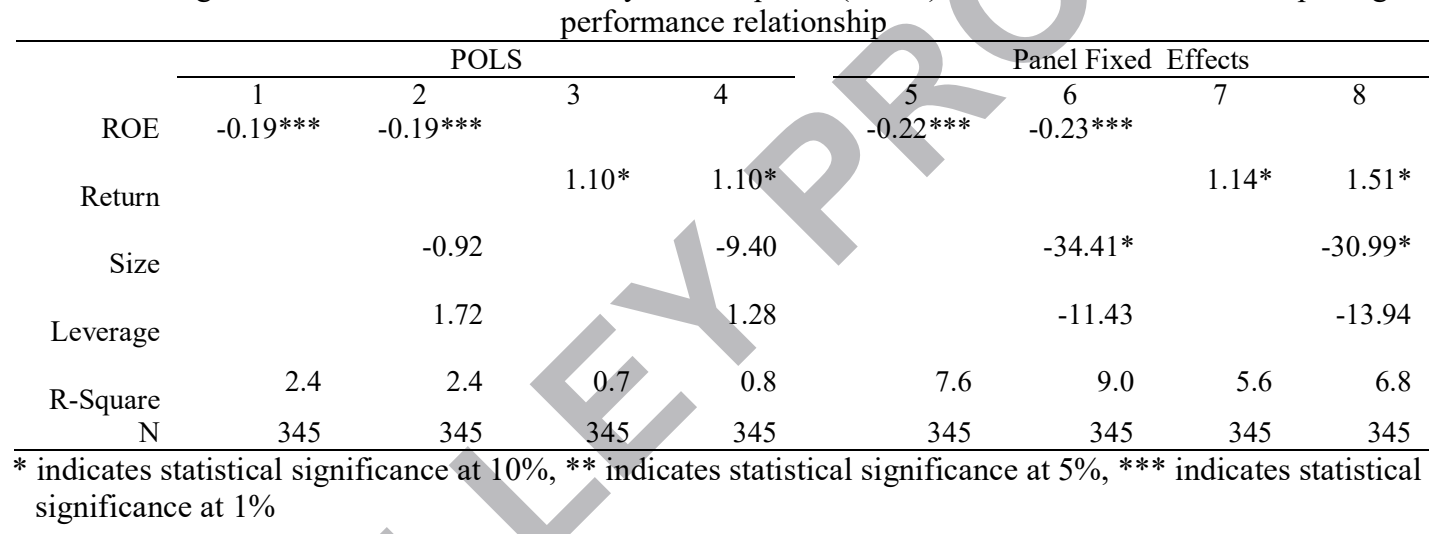

Table No. 3 summarizes the results of all the models or specifications wherein Model 1,2,3 and 4 gives the result of POLS and the other four models gives out the result of FE or LSDV(Least square dummy variable) estimates. Ceteris paribus, ROE shows a significant negative relationship (-0.19) and investors return (1.10) gives a significant positive relationship to the directors'/executive compensation in all the specifications of both the models. When firm fixed effects are controlled, firm size shows a significant negative relationship while leverage shows no significance to incentive pay. Use of Fixed Effects Model has increased the percentage of R-Square keeping the number of observations same in both the cases. The total number of observations in all the above models have reduced to 345 firm-years as the first-differenced values of the dependent variable is considered. As the variable Dir_Rem ${ }_{i t}$ was not stationary at level, it was converted to first-difference; resulting to total of $345(69 \times 5)$ observations.

ESG firms are believed to be 'good social performers' which invest their wealth or derived returns for the welfare of the community. The term 'good social performers' connotes the social responsibility or obligation of the company towards the society and their efforts towards fulfilling the same. Thus instead of paying high incentives to the executives; profits are channelized into various other CSR activities. The inverse relationship of accounting measure of performance i.e. the ROE with the executive pay implies socially responsible executives would settle for lesser than what they are entitled to, even when performance is considerable; thereby supporting the conflict-resolution hypothesis. (Cai et al. 2011). Still, there exists a dilemma as both the firm performance measures depict contrasting outcomes. Therefore, we proceed for further endogeneity testing for obtaining more dynamic and reliable results. 


\section{POST-DIAGNOSTICS TEST}

Using the traditional Fixed Effects estimator might help in eliminating firm fixed effects, but still the problem of finite sample bias, heteroskedasticity, autocorrelation and endogeneity issues still do persists. In order to eradicate such problems, one-step GMM (Generalized Method of Moments) has been used as the dynamic panel estimator in the present context.

As per the selection rule, the estimate of Pooled OLS (Ordinary Least Squares) was taken as the upper-bound estimate and Fixed Effect coefficient as the lower-bound estimate to decide whether to go for System GMM or Difference GMM. The POLS estimates for ROE and Returns were -0.262 and -0.259 respectively. While, the FE estimates for both the variables were -0.234 and -0.239 respectively. Thus in the both the cases FE estimates are higher than the POLS estimates, which state that Difference GMM is downward biased and System GMM should be used.

System-GMM estimator stated by Bundell and Bond (1998) is an improvement over the difference GMM as it can accommodate more instruments in order to enhance efficiency. Generally used to address the issue of endogeneity in a set of "small T and large N" panels; System GMM builds two equations (original equation and first difference equation) to solve the above issue by taking differenced variable as instruments in the level equation. As in this particular case, the endogeneity issue might be caused by the simultaneous relationship between the performance of the firm and compensation paid to the executives.

The general form of the equation in order to address this problem is given as:

$$
\operatorname{Ln}\left(\text { Dir_Rem }{ }_{\mathrm{it}}\right)=\alpha_{0}+\delta \operatorname{Ln}(\text { Dir_Rem })_{\mathrm{it}-1}+\beta_{1} \mathrm{Y}_{\mathrm{it}}+\gamma \mathrm{Z}_{\mathrm{it}}+\varepsilon_{\mathrm{it}}
$$

Where $\operatorname{Ln}\left(\right.$ Dir_Rem $\left._{\mathrm{it}}\right)=$ dependent proxy variable as logarithm value for consolidated executive compensation for $\mathrm{i}^{\text {th }}$ company and time $t, \delta \operatorname{Ln}(\text { Dir_Rem) })_{i t-1}=$ Lagged value of incentive pay (used in case of dynamic panel estimator), $Y_{i t=}$ performance measure for ith company and time, $Z_{\mathrm{it}}=$ Vector of other related firm variables that affect the dependent variable for ith company and time $t$ and $\varepsilon_{\mathrm{it}}=$ Error term/ residuals for $i^{\text {th }}$ company and time $t$;

TABLE 4. Results for Pay-performance relationship estimation using OneStep System GMM as a Dynamic panel Estimator

\begin{tabular}{ccc}
\hline & 1 & 2 \\
\hline Dir_Rem & $-0.57 * * *$ & $-0.57 * * *$ \\
ROE & $0.24 * *$ & 3.05 \\
Return & 0.00 & 0.00 \\
Size & 9.91 & 7.70 \\
Leverage & 64.7 & 54.6 \\
Sargan Test & \\
(p-value) & 276 & 276 \\
Observations & \\
* indicates statistical significance at 10\%, ** indicates statistical \\
significance at 5\%,*** indicates statistical significance at $1 \%$
\end{tabular}

Results for System GMM estimation is given in Table 4. Model 1 of the table indicates the effect of past year pay, ROE, firm size and leverage on the on the current remuneration. While the other model depicts the impact of lagged pay, investors return, firm size and leverage on the present compensation pay. ROE and Investor Returns has been used as instrumental variables in both Model 1 and 2 respectively and Lag (2 2) is taken for both the indicators in the levels equation. After having controlled for heteroscedasticity and autocorrelation issues, the Sargan Test gives a higher significant value indicating that the instruments under consideration are valid. While past pay has a significant negative impact on the present pay (-0.57) and ROE continues to have a significant positive impact $(0.24)$ on the compensation structure when other factors are kept constant. All other measures i.e. Return, Size and Leverage show an insignificant effect on the compensation structure when GMM is applied.

\section{FINDINGS AND DISCUSSION}

This paper has depicted the link of pay-performance concept in case of socially responsible firms and is done by testing two contrasting theories- agency theory (also known as the over-investment hypothesis) and stakeholder theory (also referred to as the conflict-resolution hypothesis). The findings consistent with conflict-resolution hypothesis when past pay is excluded, showing that firm performance has a significant impact on the compensation paid to the executives. The final robust model i.e. the One Step GMM shows persistence in executive compensation as lagged pay is significant. This outcome of our study is consistent with Raithatha and Komera (2016) as they also show the existence of contemporaneous relationship of the pay structure. But our study is also unique to the extent that it brings out a negative contemporaneous link with the past pay. 
Hence, it would be right to opine that there would be a reduction in remuneration paid to the executives as compared to the previous year in case of ESG firms.

When it comes to firm performance measures, the panel regression depicts a negative ROE to pay while it becomes significantly positive when past pay is taken into consideration in case of dynamic panel model (in line with Raithatha \& Komera 2016). Therefore, accounting-based measure of ROE holds importance to resolve conflict with various stakeholders. But the agency theory dominates when contemporaneous affect is taken into picture. But in both the instances, we claim that the main motto of socially-responsible firms is to divert their profits towards community betterment (as evident from the negative relationship between ROE and Pay in Table 3 as well as Lagged pay and Current pay in Table 4). On the other hand, our results also show that executive pay in case of ESG firms are ROE sensitive and not significant to Annual Sock Return in line with Chen and Huang (2010) who have argued that firms are more conscious of the returns to be paid to the investors, even though they are aware of stabilizing the principal-agent relationship. Increase in returns paid to the investors would help in reputation-building and reduction of conflict which reflects in the enhancement of pay of the executives.

Amongst the control measures, both firm size and firm leverage shows an insignificant impact to the pay. Our results confirm to the findings of Ghosh (2010) who suggest that debt pressures fail to exert a disciplinary influence on the remuneration paid to the executives. Also, non-significant firm size with pay (consistent with Jaiswall \& Firth 2009) indicates that irrespective of size of the ESG firms, optimum amount of remuneration is paid to the executives and rest of the funds are transferred towards welfare of.

\section{CONCLUSION}

This paper is an attempt to determine the firm performance impact on executive pay in case of socially responsible companies, post the implementation of Companies Act 2013 in India. The final results are in favour of pay persistence and conflict-resolution hypothesis. The ESG firms not only pay lesser remuneration in order to mitigate agency conflicts, but also are concerned towards maximizing returns to investors. But, bigger size firms having higher debt component doesn't have a significant influence on the top-executive pay. The findings of our paper shall be useful to policy-makers, industrialists, educators and related stake-holders for taking effective decisions.

The present study is limited to the Indian context as the legal and regulatory aspect of the Corporate Law varies across different countries. Data availability formed a major constraint owing to which more number of companies couldn't be taken into consideration. We have also not considered the pay-performance effect pre-implementation of 2013 legislation. Further studies can focus on overcoming these limitations by including more countries and different time periods. Moreover, other board-specific or firm-specific controls can also be included in the model to provide better accurate results. Using of various environmental, social and governmental factors for analysis will also broaden the scope of the study and provide clarity to the results by giving a new dimension to the study.

\section{ACKNOWLEDGEMENT}

We are indebted to the anonymous reviewers for their valuable comments and suggestions

\section{NOTES}

1 Section 197 of Companies Act 2013 has an elaboration in detail about the maximum managerial remuneration to be paid in case of profits and in case of inadequate profits (Schedule V).

2 Although other measures like Return on Assets (ROA) and Return on Capital Employed (ROCE) have also been used by previous papers as a proxy for accounting measure of performance, we have used Return on Equity as it is also a widely used measure that is also affected by number of shares outstanding that would also act as an effective measure for determining executive compensation (Zhang et al. 2017)

3 Stock return are the most widely used measure of market performance and is used as a proxy for firm financial performance (Gentry and Shen 2010) as it is more efficient in reflecting managers' actions in firm-value determination through the market-price movements (Cadman et al. 2010)

\section{REFERENCES}

Abowd, J. M., \& Kaplan, D. S. 1999. Executive compensation: six questions that need answering. Journal of Economic Perspectives 13(4): 145-168.

Al Farooque, O., Buachoom, W., \& Hoang, N. 2019. Interactive effects of executive compensation, firm performance and corporate governance: Evidence from an Asian market. Asia Pacific Journal of Management 36(4): 1111-1164.

Amewu, G., \& Paul Alagidede, I. 2021. Mergers, executive compensation and firm performance: The case of Africa. Managerial and Decision Economics 42(2): 407-436.

Barnea, A., \& Rubin, A. 2010. Corporate Social Responsibility as a Conflict Between Shareholders. Journal of Business 
Ethics 97(1): 71-86.

Blundell, R., \& Bond, S. 1998. Initial conditions and moment restrictions in dynamic panel data models. Journal of Econometrics 87(1): 115-143.

Brisley, N., Cai, J., \& Nguyen, T. 2021. Required CEO stock ownership: Consequences for risk-taking and compensation. Journal of Corporate Finance 66.

Cadman, B., Klasa, S., \& Matsunaga, S. 2010. Determinants of CEO pay: A comparison of ExecuComp and non-ExecuComp firms. The Accounting Review 85(5): 1511-1543.

Cai, Y., Jo, H., \& Pan, C. 2011. Vice or virtue? The impact of corporate social responsibility on executive compensation. Journal of Business Ethics 104(2): 159-173.

Chakravarthy, B. S. 1986. Measuring strategic performance. Strategic Management Journal 7(5): 437-458.

Chan, M. C., Watson, J., \& Woodliff, D. 2014. Corporate Governance Quality and CSR Disclosures. Journal of Business Ethics 125(1): 59-73.

Chen, C. R., \& Huang, Y. S. 2010. Simultaneous estimation of executive compensation and firm performance in the banking industry. Advances in Quantitative Analysis of Finance and Accounting (8): 101-135.

Clarkson, M. B. E. 1995. A Stakeholder Framework for Analyzing and Evaluating Corporate Social Performance. The Academy of Management Review 20(1): 92-117.

Core, J. E., Holthausen, R. W., \& Larcker, D. F. 1999. Corporate governance, chief executive officer compensation, and firm performance. Journal of Financial Economics 51(3): 371-406.

Economic Times Intelligence Group. 2018.India Inc's top executives earn 243 times more than average staff. Retrieved 27 November 2019 from https://economictimes.indiatimes.com/news/company/corporate-trends/india-incs-topexecutives-earn-243-times-more-than-average-staff/articleshow/63359591.cms

ET Prime. 2019. Altico faces RBI ire for showering CEO with INR10 crore even as lenders knock on the door. Retrieved 27 November 2019 from https://prime.economictimes.indiatimes.com/news/72132850/corporate-governance/alticofaces-rbi-ire-for-showering-ceo-with-inr10-crore-even-as-lenders-knock-on-the-door

Firth, M., Fung, P. M., \& Rui, O. M. 2006. Corporate performance and CEO compensation in China. Journal of Corporate Finance 12(4): 693-714.

Freeman, R. E. 1984. Stakeholder management: framework and philosophy. Pitman, Mansfield, MA.

Gangi, F., Meles, A., D'Angelo, E., \& Daniele, L. M. 2019. Sustainable development and corporate governance in the financial system: Are environmentally friendly banks less risky?. Corporate Social Responsibility and Environmental Management 26(3): 529-547.

Gao, L., \& Zhang, J. H. 2013. Firms' Earnings Smoothing, Corporate Social Responsibilities, and Valuation. Journal of Corporate Finance, 32: 108-127.

Gentry, R. J., \& Shen, W. (2010). The relationship between accounting and market measures of firm financial performance: How strong is it?. Journal of managerial issues 22(4): 514-530.

Ghasemi, M., \& Ab Razak, N. H. 2020. What Determines Executives' Remuneration in Malaysian Public Listed Companies?. Asian Journal of Accounting and Governance 13(1): 27-39.

Ghosh, A. 2003. Board structure, executive compensation and firm performance in emerging economies: Evidence from India. Indira Gandhi Institute of Development Research Working Paper, 91-9819090266.

Ghosh, S. 2006. Do board characteristics affect corporate performance? Firm-level evidence for India. Applied Economics Letters 13(7): 435-443.

Ghosh, S. 2010. Firm performance and CEO pay: Evidence from Indian manufacturing. The Journal of Entrepreneurship 19(2): 137-147.

Griffin, J. J., \& Mahon, J. F. 1997. The corporate social performance and corporate financial performance debate: Twentyfive years of incomparable research. Business and Society 36(1): 5-31.

Hasnan, S., Razali, M. H. M., \& Hussain, A. R. M. 2020. The effect of corporate governance and firm-specific characteristics on the incidence of financial restatement. Journal of Financial Crime 28(1): 244-267

Jaiswall, M., \& Firth, M. 2009. CEO pay, firm performance, and corporate governance in India's listed firms. International Journal of Corporate Governance 1(3): 227-240.

Jaiswall, S. S. K., \& Bhattacharyya, A. K. 2016. Corporate governance and CEO compensation in Indian firms. Journal of Contemporary Accounting \& Economics 12(2): 159-175.

Jensen, M. C. 1986. Agency costs of free cash flow, corporate finance, and takeovers. The American Economic Review 76(2): 323-329.

Jensen, M. C., \& Meckling, W. H. 1976. Theory of the firm: Managerial behavior, agency costs and ownership structure. Journal of Financial Economics 3(4): 305-360.

Jensen, M. C., \& Murphy, K. J. 1990. Performance pay and top-management incentives. Journal of Political Economy 98(2): 225-264.

Jo, H., \& Harjoto, M. A. 2011. Corporate Governance and Firm Value: The Impact of Corporate Social Responsibility. Journal of Business Ethics 103(3): 351-383.

John, T. A. \& K. John, 1993. Top-management compensation and capital structure, Journal of Finance 48: 949-74.

Karwowski, M., \& Raulinajtys-Grzybek, M. 2021. The application of corporate social responsibility (CSR) actions for 
mitigation of environmental, social, corporate governance (ESG) and reputational risk in integrated reports. Corporate Social Responsibility and Environmental Management.

Khanna, T., \& Palepu, K. 2000. Is group affiliation profitable in emerging markets? An analysis of diversified Indian business groups. The Journal of Finance 55(2): 867-891.

Kim, E. H., \& Ouimet, P. 2014. Broad-based employee stock ownership: Motives and outcomes. Journal of Finance 69(3): $1273-1319$.

Kotabe, M., Hamilton, R. D., \& Balsam, S. 2017. Executive compensation: An examination of the influence of TMT compensation on risk-adjusted performance. Journal of Strategy and Management 10(2): 187-205

Lewellen, W., C. Loderer, and K. Martin. 1987. Executive compensation and executive incentive problems, Journal of Accounting and Economics 9(3): 287-310.

Malik, M., \& Shim, E. D. 2019. An Empirical Examination of Economic Determinants of Financial CEO Compensation: A Comparative Study on Pre-and Post-Financial Crisis Periods. In Advances in Management Accounting, eds L.L.Burney \& M.A.Malina 31:23-53. Emerald Publishing Limited.

McGuire, J. B., Sundgren, A., \& Schneeweis, T. 2018. Corporate Social Responsibility and Firm Financial Performance. Academy of Management Journal 31(4): 854-872.

Mehran, H. 1995. Executive compensation structure, ownership, and firm performance. Journal of Financial Economics 38(2): 163-184.

Milbourn, T. T. 2003. CEO reputation and stock-based compensation. Journal of Financial Economics 68(2): $233-262$.

Miles, P. C., \& Miles, G. 2013. Corporate social responsibility and executive compensation: Exploring the link. Social Responsibility Journal 9(1): 76-90.

Moneycontrol Contributer. 2019. Indian CEO pay has outpaced company performance in the past five years. Retrieved 30 December 2019 from https:/www.moneycontrol.com/news/business/companies/indian-ceo-pay-has-outpacedcompany-performance-in-the-past-five-years-3725691.html

Mukhtaruddin, M., Ubaidillah, U., Dewi, K., Hakiki, A., \& Nopriyanto, N. 2019. Good Corporate governance, Corporate social responsibility, Firm value, and Financial performance as Moderating Variable. Indonesian Journal of Sustainability Accounting and Management 3(1): 55-64

Murphy, K. J. 1999. Executive compensation. In Handbook of Labor Economics, eds O.C. Ashenfelter \& D. Card 24852563. Elsevier.

Nelling, E., \& Webb, E. 2009. Corporate social responsibility and financial performance: The "virtuous circle" revisited. Review of Quantitative Finance and Accounting 32(2): 197-209.

Nicola, C., Giuseppe, M., Martina, C., \& Giuseppe, S. 2016. Relationship between CEO pay and total shareholder return: an empirical analysis in the Italian context. Corporate Ownership \& Control 13(4): 182-187.

Parthasarathy, A., Menon, K., \& Bhattacherjee, D. 2006. Executive compensation, firm performance and governance: an empirical analysis. Economic and Political Weekly, 41(39): 4139-4147.

Rahim, S. A., \& Nelson, S. 2018. Directors' Influence on Pay-Based Performance. Asian Journal of Accounting and Governance 9(1):11-26.

Raithatha, M., \& Komera, S. 2016. Executive compensation and firm performance: Evidence from Indian firms. IIMB Management Review 28(3):160-169

Rasoava, R. 2019. Executive compensation and firm performance: a non-linear relationship. Problems and Perspectives in Management 17(2): 1-17.

Ronald, S., Ng, S., \& Daromes, F. E. 2019. Corporate Social Responsibility as Economic Mechanism for Creating Firm Value. Indonesian Journal of Sustainability Accounting and Management 3(1): 22-36.

Ross, S. A. 1977. The determination of financial structure: The incentive signaling approach. Bell Journal of Economics 8(1): 23-40.

Tosi, H. L., Werner, S., Katz, J. P., \& Gomez-Mejia, L. R. 2000. How much does performance matter? A meta-analysis of CEO pay studies. Journal of Management 26(2): 301-339.

Waddock, S. A., \& Graves, S. B. 1997. The corporate social performance-financial performance link. Strategic Management Journal 18(4): 303-319.

Wright, P., \& Ferris, S. P. 1997. Agency conflict and corporate strategy: The effect of divestment on corporate value. Strategic Management Journal 18(1): 77-83.

Yang, C., Singh, P., \& Wang, J. 2020. The effects of firm size and firm performance on CEO pay in Canada: A ReExamination and Extension. Canadian Journal of Administrative Sciences 37(3): 225-242.

Zhang, B., Yuan, H., \& Zhi, X. 2017. ROE as a performance measure in performance-vested stock option contracts in China. Frontiers of Business Research in China 11(1): 1-17. 
Chetna Rath*

Department of Commerce

School of Management

Pondicherry University

(PIN-605014) Puducherry

INDIA.

E-mail: rathchetna@gmail.com

\section{Malabika Deo}

Department of Commerce

School of Management

Pondicherry University

(PIN-605014) Puducherry

INDIA.

E-mail: deo_malavika@yahoo.co.in

*Corresponding author 